\title{
VIEW AND MANAGEMENT OF INNOVATIVENESS UPON SUCCESSION IN FAMILY-OWNED SMES
}

Christina Grundström, Christina Öberg and Anna Öhrwall Rönnbäck

\section{Linköping University Post Print}

N.B.: When citing this work, cite the original article.

Original Publication:

Christina Grundström, Christina Öberg and Anna Öhrwall Rönnbäck, VIEW AND MANAGEMENT OF INNOVATIVENESS UPON SUCCESSION IN FAMILY-OWNED SMEs, 2011, International Journal of Innovation Management, (15), 3, 617-640.

http://dx.doi.org/10.1142/S136391961100326X

Copyright: World Scientific Publishing http://www.worldscinet.com/

Postprint available at: Linköping University Electronic Press

http://urn.kb.se/resolve?urn=urn:nbn:se:liu:diva-71202 


\title{
View and management of innovativeness upon succession in family-owned SMEs
}

\author{
Christina Grundström* \\ Linköping University, Department of Management and Engineering, \\ SE-581 83 Linköping, Sweden. \\ E-mail: christina.grundstrom@liu.se
}

\section{Christina Öberg}

Manchester Business School, The University of Manchester, Booth

Street West, Manchester M15 6PB, UK

E-mail: christina.oberg@liu.se

\author{
Anna Öhrwall Rönnbäck \\ Linköping University, Department of Management and Engineering, \\ SE-581 83 Linköping, Sweden. \\ E-mail anna.ohrwall.ronnback@liu.se \\ * Corresponding author
}

\begin{abstract}
The purpose of this paper is to provide insights into how the successors of family-owned manufacturing SMEs view and manage innovativeness. Research into company take-overs mainly focuses on large companies and little is known about innovativeness in research on familyowned businesses, often SMEs. This paper presents findings from ten company successions, five of which describe family successions and five external ones. The paper shows that there is little difference in how various types of successor view and manage innovativeness. A successor is chosen with care and this also influences the view and management of innovativeness: other criteria seem to apply in the succession and any (radical) changes can only be introduced if a number of contextual factors are managed properly.
\end{abstract}

Keywords: Succession; family-owned manufacturing SMEs; innovativeness; acquisition; take over; radical vs incremental innovation..

\section{Why innovativeness, successions and SMEs}

Few researchers and practitioners would question that companies need to innovate and to remain innovative to stay in business. It is also evident, that most companies at one point or another get a new owner. Research on acquisitions usually focuses on large companies (At and Morand, 2003; Davidson, 1988; Hussinger, 2010). When innovative capability or innovativeness is considered in the acquisition literature, it is usually done from the 
perspective of a large firm acquiring a small, innovative unit (Ahuja \& Katila, 2001; Christensen, 2006; de Man \& Duyster, 2005). Acquisition studies including small or medium-sized companies (SMEs) as both acquirers and targets remain limited. Similarly, the very idea of acquisitions of innovative firms seems to imply that these are newly established actors, with limited experience of acting as sovereign units (Boeker \& Karichalil, 2002; Fillion, 1966). However, many SMEs are run as small firms through their entire lifetime. Such firms, as well as any other companies, need to update their product range, improve production processes, and possibly diverse their businesses into new fields, thus they need to remain innovative. It is also a fact that SMEs contribute significantly to the economy in many countries. In Sweden 6 out of 10 employees in the private sector are employed by SMEs and more than half of the industry's contribution to the Swedish GNP comes from SMEs (Ljung, 2010). SMEs are mostly family-owned businesses (European Commission, 2009).

In general the handing over of a business to new owners is referred to as succession, and in many cases such handing over is planned and thus referred to as Business Succession Planning. In this paper we use a definition of this based on Ip and Jacobs (2006, p. 326-327): The transfer of a business resulting from the owner's wish to leave the business for some reason (including retiring). The succession can involve a transfer of the ownership to members of the owner's family, employees, or external buyers. Successful succession results in a continuation of the business, at least in the short term.

Succession by someone in the near family is the most frequent ownership change in family-owned companies. Such ownership change is often considered problematic, where researchers have focused their attention to integration issues (Melin, Brundin, Haag, Hall, Nordqvist, and Wigren, 2007), while less is known about innovation aspects of such ownership changes. Habbershon, Nordqvist and Zellweger (2010) have studied how ideas are passed through generations and mindsets of entrepreneurial individuals; something that they state is a new area of study in family takeovers. Yet, our aim is to look at innovativeness (and their associated innovations) related to succession focusing more on how succession and (continued) innovativeness interrelates, rather than family competences and capabilities per se. Furthermore, we include family-businesses that are succeeded to external parties, a field that has been given limited research attention. It seems like even less is known about innovativeness when the family-owned company gets other types of new owners, such as currently employed managers (management buyout), or external parties such as management buy-in (Scholes, Wright, Westhead, Burrows \& Bruining, 2007), a company group, or a venture capitalist. What is known though is that family-owned companies behave differently depending on the extent of involvement by the CEO's relatives as employees, key managers, advisors, and board members (Fiegener, 2010). From this recent research it is still unclear how the new owners view and manage innovativeness.

With family-owned businesses, often SMEs, constituting an important part of business life in many countries, and innovativeness seen as key to firm survival in the long run, a deeper understanding of succession and continued innovativeness contributes to helping family-owned businesses prosper long-term. Such insights are important for not only family-owned businesses but also advisors to family members and small-scale investors interested in acquiring a family-owned SME. 


\section{Purpose}

The purpose of this paper is to provide insights into how the successors of family-owned SMEs view and manage innovativeness by answering the following questions:

- Depending on to whom a family-owned SME is succeeded, how can the innovativeness following the succession be characterized?

- How can the aspects explaining the innovativeness following succession in a familyowned SME be described?

\section{Theories serving as foundation}

\section{Innovativeness in SMEs - what it is and what may influence}

How can then innovativeness be defined? In general, innovativeness can be defined as "the notion of openness to new ideas as an aspect of a firm's culture" (Hurley and Hult 1998, p. 44) and relates to the organization's orientation towards innovation (Hurley and Hult, 1998; LaForet and Tann, 2006). Verhees and Meulenberg (2004) interpret innovativeness as a willingness of the owner to learn about and to adopt innovations, both in the input and output markets, and thus relates innovativeness to personal traits of creativity and conscious decisions taken on how to be open to new ideas. Yet, high innovativeness is not equal to the owner being innovative within all areas (ibid.). What may hinder or foster innovativeness? Verhees and Meulenberg draw on Kirton (1976, in Verhees and Meulenberg, 2004) who shows that the type of creativity and decisionmaking is highly individual and can vary from adaptive to innovative. In general, adaptors can be said to prefer to do things better within the generally accepted (and given) frame of thought while innovators prefer to do things differently as they redefine the problem, turning away from given frameworks and accepted thoughts (ibid.).

As for SMEs, in a study of Spanish SMEs, Madrid-Guijarro, Garcia and Van Auken (2009) noted that the most significant barrier to product, process and management innovation was cost, and the smaller the firm, the bigger the impact of this, while manager or employee resistance was the least significant. This means that even though the new owner may per se be open to innovations, the cost may be too high for the firm to bear. In their study, LaForet and Tann (2006) found that the drivers of innovativeness in manufacturing SMEs (SMME) were: market anticipation, customer focus, commitment of CEO or owners in new product development and processes, and new ways of working. The companies with "high" innovativeness had innovation as part of the business strategy and were goal-oriented with their innovation activities. As other studies discuss (e.g. Storey, 1994, in Eng, Ledwith and Bessant, 2010), LaForet and Tann (2006) found that innovation in SMMEs is based more around developing new processes than new product innovations. In addition they found that a certain ability to adopt innovations cannot be related to a specific use of technology or management of process innovations. Since the studied SMMEs had a tradition of being inward-looking, they displayed difficulties in acquiring new knowledge and were dependent on present customers. 
Verhees and Meulenberg (2004) show that market orientation as expressed by using customer market intelligence has a positive effect on SME performance since quality, service and market timing likely is enhanced. Furthermore, they discuss that market orientation concerning the augmented product enhances the chances to become a preferred supplier as such knowledge goes beyond the product (goods or service). In addition, they recommend that SMEs operating in markets with homogenous products use customer market intelligence to develop an appealing mix of products to gain differentiation. Still, Verhees and Meulenberg (2004) found that market orientation has to be related to the innovativeness of the company. Very entrepreneurial owners of SMEs may be toned down by market intelligence while those less entrepreneurial may be stimulated by it. Intelligence on suppliers has a similar effect (Verhees and Meulenberg, 2004). Still, there are some warnings about listening too much to present customers and suppliers as they may represent too static an environment. Dosi's (1982) concept of technological trajectories implies innovations or new product development in small or large steps but in a particular and "confined" direction. It is also argued that path dependencies, co-specific assets, and the learning and understanding of old products (as represented by the products the customer always has wanted, albeit enhanced over time) create inertia and a tendency to stick to established standards and technology development trajectories (Tushman \& Murmann, 1998; Dosi, 1982; Clark, 1985; Sahal, 1981; Levinthal, 1997). To take up the opportunities of new trajectories or paths it is important that any firm gain the skills of de-learning and adapting to new environments (Garud, Nayyar \& Shapira, 1997); in other words, skills necessary to maintain innovativeness.

How then do this more "hands-on"? Eng, Ledwith and Bessant (2010) discuss the terms "exploit" and "explore" in relation to innovations. A company's present customers will be satisfied by "exploit” behaviour as it aims to improve the company's current products or develop new products based on a variation of the technologies currently in use. New markets can be opened by the "explore" behaviour where existing products or underlying /technologies are adapted to the needs of the new market, or when different technologies than those in use, serve as the base for new products. After a phase of "explore” most companies "exploit” within the newly explored area(s). Eng, Ledwith and Bessant (2010) suggest that within an established frame (or "thought pattern") two search patterns for innovations can be detected. Exploit for incremental innovations and Bounded exploration for radical innovations. If the frame can be classified as new (where the environmental complexity is high and "thought patterns" yet vague) there are two other search patterns. Reframing for incremental innovations and Co-evolve for radical innovation. The basic characteristics for each are summarized in Table 1.

Table 1 Search patterns for types of innovativeness

\begin{tabular}{ll}
\hline Search pattern & Characteristics \\
\hline Exploit & $\begin{array}{l}\text { "Business" as usual with incremental extensions of market and technology in use } \\
\text { employing good practice working closely with customers with an established } \\
\text { organization highly involved }\end{array}$ \\
$\begin{array}{l}\text { Bounded } \\
\text { exploration }\end{array}$ & $\begin{array}{l}\text { strategic knowledge sources applying more of "open innovation" (to benefit from } \\
\text { the strategic knowledge sources) implemented in a specialized organization. }\end{array}$
\end{tabular}




\begin{tabular}{ll} 
Search pattern & Characteristics \\
\hline Reframing & $\begin{array}{l}\text { Taking in new elements in environment exploring various options putting } \\
\text { importance on breadth and depth using front-line techniques exploring } \\
\text { technology and market using internal and external scouts. }\end{array}$ \\
Co-evolve & $\begin{array}{l}\text { New to the world possibilities in undetected grounds co-evolving with } \\
\text { stakeholders using complexity theory and internal and external licensed } \\
\text { dreamers. }\end{array}$
\end{tabular}

Source: Based on Eng, Ledwith and Bessant (2010).

\section{Acquisitions and succession}

Research on succession in SMEs remains limited (At and Morand, 2003; Hussinger, 2010). Possibly the small firm appears as the target being taken over by a large company. Such deals are often sealed to reach growth abilities, strengthening the SME's financial situation and thereby also its probability to be accepted by customers (Fillion, 1966; Öberg, Grundström \& Jönsson, 2011). Hussinger (2010) adds to this the importance of technological relatedness between parties as important in the acquisition of SMEs, also pointing to the acquirer's absorptive capacity as important for the success of such a takeover. Graves (1981) is one exception to these large-firm-acquires-small-firm studies. In his article, he researches various parties' attitudes towards the merger of two small companies, pointing to how it led to better market coverage and product mixes, for instance, and Salvato, Lassini and Wiklund (2007) describe acquisitions as a growth opportunity for small entrepreneurial firms, through focusing on the process of such successions.

In the circumstance of within-family succession, research by Birley, Ng and Godfrey (1999) points to various dimensions of such succession: how children may be unwilling to take over the firm, risks for mixtures between private family affairs and the business, and whether the succession should evolve over several years, or mean that the next generation takes over as the previous retires. Davis \& Harveston (1998) similarly research the family influences on that realisation of succession and Handler (1990) researches succession from entrepreneurs to other family-members to conclude that the entrepreneur and successor needs to adjust to each other to successfully complete the overtaking. Later research by Rastologi and Agrawal (2010) finds that children of Indian business families can be divided into two groups: Potential Successors and Potential Entrepreneurs. Potential Successors are those that express interest in joining the family business either due to free will or family pressure. Further, they usually have low selfesteem and feel fulfilled by joining the family business and display low risk taking, as they do not wish to jeopardize the family business. Potential Entrepreneurs on the other hand feel no pressure to join the family business, have high self-esteem, a wish to bring strategic change into action and are likely to adopt to changes to ensure sustainable growth Trevinyo-Rodriguez and Bontis (2010) investigate how family impacts the integration of companies in terms of knowledge transfer. Focus is however on how such succession is completed successfully, not on what happens with the business afterwards. Ip and Jacobs (2006) summarise those topics and perspectives mostly taken in research on succession to: family and business, legal, finance and tax issues, other barriers, and practical approaches to the succession. Consequently, the transaction phase dominates in 
the literature, as does themes of information asymmetry and pricing related to it (Razssino and Reuer, 2007, Scholes, Wright, Westhead, Burrows \& Bruining, 2007), while less is known about succession consequences. In those instances where outcome is considered (e.g., Zajac, 1990), it is mostly measured as stock market prices, revenue and the like, while specific items such as innovativeness has to our knowledge not been researched.

\section{How the study was carried out}

The paper adopts a multiple case study with a multiple-data source approach. The selection of cases was based on theoretical sampling to illustrate the theoretical constructs (Eisenhardt and Graebner, 2007) highlighted in this paper. The data for the cases were all taken from a database containing 150 small manufacturing companies (SMMEs) within 250 kilometre radius from Linköping, Sweden (i.e. mid-southeast of Sweden). These companies have all been subject to in-depth individual case studies 2005-2010 in a Linköping University master-level business course. One of the authors is the course examiner of this course and has thorough knowledge of the SMEs, and has had personal contact with and visited several of the studied companies. Within this course, several company visits are conducted, and the strictly confidential results of the students' analysis are reported on site to company owners and top management, followed by an indepth discussion about company development. A university teacher leads this meeting.

To select companies, we used the definition for family-owned SMEs as proposed by European Commission (2009) and Commission Recommendation (2003). In all, ten (10) manufacturing SMEs were selected, yet from somewhat varying industries to obtain between-case contrast (as suggested by Eisenhardt and Graebner, 2007). Five of the companies represent succession within the family and five to new external owners. All companies remained SMEs following the succession. In some SMEs the succession was not finalized and that constituted an opportunity to study real time data (cf. Eisenhardt and Graebner, 2007). In all cases the succession had been initiated or completed within the past ten years. In order to answer the research questions, various types of secondary data, mainly the in-depth case study material from the business course, were scrutinized but also interviews were conducted, when accessible, with the new owners.

Since the aim of the paper is to provide insights into how the successors of familyowned SMEs view and manage innovativeness by answering questions about how innovativeness (depending on type of succession) can be characterized, and how the aspects explaining the innovativeness following succession in a family-owned SME can be described, the classifications (and their descriptions) identified in the literature studied were used in the analysis to put labels on the studied SMEs. The company serves as the unit of analysis. In the same manner as Mosey, Clare and Woodcock (2001), the companies were classified either as "radical innovators" or "incremental improvers". As a starting point for classification of innovativeness the research by Eng, Ledwith and Bessant (2010) was used. As recommended by Pratt (2009) tables and graphs were used to give an overview of the data and to facilitate and illustrate the analysis. 
Table 2 Presentation of case companies

\begin{tabular}{|c|c|c|c|c|c|c|c|}
\hline Company & $\begin{array}{l}\text { Established } \\
\text { year }\end{array}$ & Acquisition type & Size & Field of business & $\begin{array}{l}\text { View on management of } \\
\text { innovativeness before and } \\
\text { after }\end{array}$ & $\begin{array}{l}\text { Type of innovator } \\
\text { (radical/incremental) }\end{array}$ & $\begin{array}{l}\text { Type of environment } \\
\text { (established/new frame) }\end{array}$ \\
\hline Company F1 & 1936 & $\begin{array}{l}\text { Within family, } \\
\text { continuously, now } \\
\text { 3rd generation }\end{array}$ & $\begin{array}{l}25 \mathrm{M} € \\
56 \text { employees }\end{array}$ & $\begin{array}{l}\text { Development and } \\
\text { manufacturing to bakery } \\
\text { industry, } 90 \% \text { export }\end{array}$ & $\begin{array}{l}\text { No change identified. Strong } \\
\text { focus on family unity within } \\
\text { family. }\end{array}$ & $\begin{array}{l}\text { Mainly incremental but also } \\
\text { radical. Little use of customer } \\
\text { market intelligence available. }\end{array}$ & Established \\
\hline Company F2 & $1940 \mathrm{~s}$ & Within family & $\begin{array}{l}\text { 6,5 M€ } \\
45 \text { employees }\end{array}$ & $\begin{array}{l}\text { Contract manufacturing, } \\
\text { no export }\end{array}$ & No change identified. & $\begin{array}{l}\text { Incremental with production } \\
\text { process innovation in focus. } \\
\text { Some supplier intelligence. }\end{array}$ & Established \\
\hline Company F3 & 1997 & $\begin{array}{l}\text { Within family (on- } \\
\text { going) }\end{array}$ & $\begin{array}{l}1,4 \mathrm{M} € \\
10 \text { employees }\end{array}$ & Contract manufacturer & Growth intention. & Incremental & Established \\
\hline Company F4 & 1970s & Within family & $\begin{array}{l}3,5 \mathrm{M€} \\
23 \text { employees }\end{array}$ & $\begin{array}{l}\text { Children's playground } \\
\text { manufacturer }\end{array}$ & No change identified. & $\begin{array}{l}\text { Incremental (technology), close } \\
\text { co-operation with customers. } \\
\text { Customer market intelligence. }\end{array}$ & $\begin{array}{l}\text { Established and new frames } \\
\text { (depending on product } \\
\text { group) }\end{array}$ \\
\hline Company F5 & 1908 & $\begin{array}{l}\text { Within family } \\
\text { combined with } \\
\text { management buy-in }\end{array}$ & $\begin{array}{l}2,8 \mathrm{M} € \\
30 \text { employees }\end{array}$ & $\begin{array}{l}\text { Automated industrial } \\
\text { lubrication }\end{array}$ & Only minor changes. & $\begin{array}{l}\text { Radical for small part of business, } \\
\text { incremental for rest }\end{array}$ & $\begin{array}{l}\text { For small part of business on } \\
\text { verge to new frame (ahead of } \\
\text { customers in business idea), } \\
\text { rest established }\end{array}$ \\
\hline $\begin{array}{l}\text { Company } \\
\text { N1 }\end{array}$ & 1886 & $\begin{array}{l}\text { External owners } \\
\text { (industry group in } \\
\text { same industry) }\end{array}$ & $\begin{array}{l}5,2 \mathrm{M} € \\
25 \text { employees }\end{array}$ & Components to motors & $\begin{array}{l}\text { No change, early days (19th } \\
\text { century) radical innovation }\end{array}$ & $\begin{array}{l}\text { Incremental; last century } \\
\text { incremental improvements of } \\
\text { radical innovation }\end{array}$ & $\begin{array}{l}\text { Mainly established, } \\
\text { somewhat new frame }\end{array}$ \\
\hline $\begin{array}{l}\text { Company } \\
\text { N2 }\end{array}$ & 1956 & $\begin{array}{l}\text { Management buy-in } \\
\text { (after bankruptcy } \\
\text { acquired by industry } \\
\text { conglomerate) }\end{array}$ & $\begin{array}{l}3,5 \mathrm{M} € \\
50 \text { employees (last } \\
\text { year before } \\
\text { bankruptcy) }\end{array}$ & Truck equipment & $\begin{array}{l}\text { Aimed to double turnover in } \\
\text { couple of years, develop new } \\
\text { products }\end{array}$ & Incremental & Established \\
\hline $\begin{array}{l}\text { Company } \\
\text { N3 }\end{array}$ & 1984 & $\begin{array}{l}\text { Management buy-in } \\
\text { mixed with external } \\
\text { owner }\end{array}$ & $\begin{array}{l}2,3 \mathrm{M€} \\
13 \text { employees }\end{array}$ & $\begin{array}{l}\text { Plastic components } \\
\text { manufacturer (non- } \\
\text { contract) }\end{array}$ & No change identified. & Incremental & $\begin{array}{l}\text { Mainly established, some } \\
\text { new frame }\end{array}$ \\
\hline $\begin{array}{l}\text { Company } \\
\text { N4 }\end{array}$ & 1961 & $\begin{array}{l}\text { External owners } \\
\text { (industry } \\
\text { conglomerate) }\end{array}$ & $\begin{array}{l}\text { 7,8 M€ } \\
42 \text { employees }\end{array}$ & $\begin{array}{l}\text { Contract manufacturer } \\
\text { (plastics) }\end{array}$ & Focus on process innovation & Incremental & Established \\
\hline $\begin{array}{l}\text { Company } \\
\text { N5 }\end{array}$ & 1953 & Management buy-in & $\begin{array}{l}1,7 \mathrm{M} € \\
18 \text { employees }\end{array}$ & Plastic coating & Ambition to grow sustainably & $\begin{array}{l}\text { Incremental. Some customer } \\
\text { market intelligence }\end{array}$ & Established \\
\hline
\end{tabular}

Source: Company background data (columns 1-5) from case data base, Center for Applied Management in SMEs (CAM), Linköping

University 2010. 


\section{Presentation of cases}

Table 2 presents the companies studied where the classifications in the three columns to the right are based on Rastologi and Agrawal, 2010, Mosey et al., (2001) and Eng et al., (2010) respectively. The companies all qualify as SMMEs with up to fifty some employees and turnovers up to $25 \mathrm{M} €$, and all were so also at the time of their successions. The company locations in the mid-southeast of Sweden means that they are embedded in an industry structure often characterized by small companies built on technology-orientated manufacturing skills, which applies also to the companies studied. Several of these act as sub-suppliers to other manufacturing firms in the region, and specialize in plastics or metal refinement work, while the rest of them have developed stand-alone products often sold to industrial buyers. Based on the case selection, five of the companies were succeeded to family-members (marked "F" in Table 2), and five to new external owners (marked " $\mathrm{N}$ " in the table). Two of the companies (F1 and F2) had been succeeded within the family for several generations, while the other three family successions were first generation take-overs, in one case by a previously external company (F5). In the case of F5, the most recent succession was combined with a management buy-in. As for the external successions, two of these describe how an industry conglomerate bought into the company (N1 and N4), two management buy-in (N2 and N5), and one (N3) was a mix of management buy-in and succession of an external party not active in an executing position. Company N2 (succession in 2007) went bankrupt in fall 2008, and the assets were acquired by an industry conglomerate early 2009.

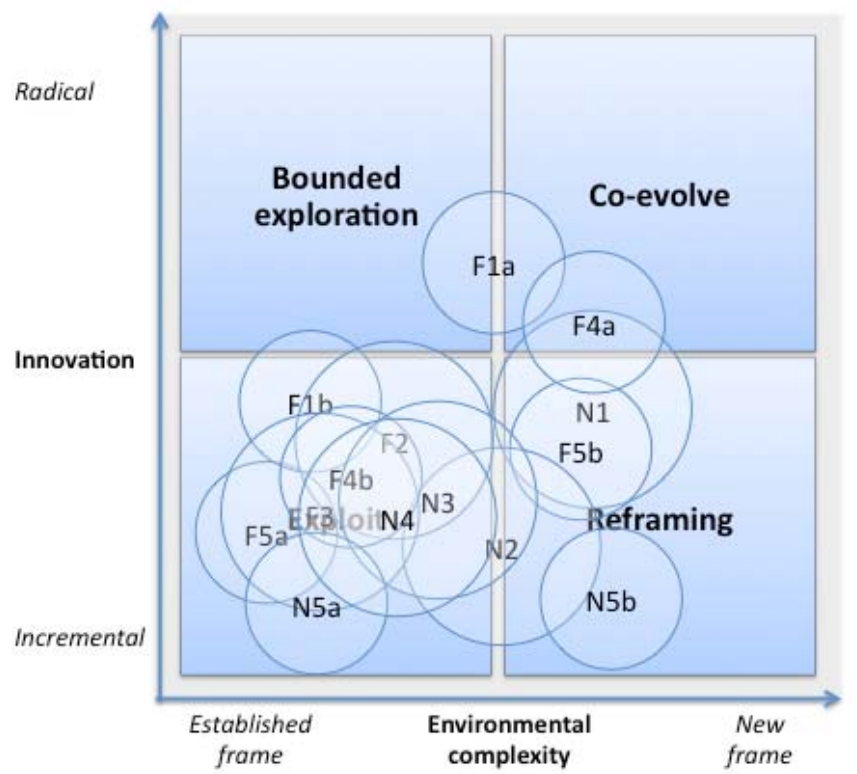

Figure 1 Search patterns for types of innovativeness: mapping of studied cases (based on framework by Eng et al, 2010). 
In Figure 1 the patterns for innovations of the studied cases, are mapped, based on data from the case data base, according to the categorization suggested by Eng et al (2010), (1) on the y-axis: type of innovation, that is, radical versus incremental, and (2) on the x-axis: their environmental complexity, that is, whether they operate within an established frame or rather a new frame. The mapping shows if the company operates within an established frame with exploitation for incremental innovations or bounded exploration for radical innovations, or if the company rather exists within a new frame, reframing for incremental innovations or co-evolve for radical innovation. Some of the studied companies have two distinctly different lines of business, which are classified as (a) or (b).

\section{Analysis}

As can be noted in Table 2, the companies had before the successions somewhat different innovation profiles and these also continued to various extents following the successions, see Figure 1. There were no particular difference between the companies that were later succeeded to family members (companies marked with F in Figure 1) and those taken over by new external owners (companies marked with $\mathrm{N}$ ) concerning incremental or radical innovation styles; both categories showed mainly incremental innovation, that is to refine the current within an established setting (Eng et al 2010). All successors could also be classified as "adapters", that is, less similar to the description of "innovators" as presented by Verhees and Meulenberg (2004), and Kirton (1976). How this comes is analyzed below.

Based on the cases, it can be decided that in all but one (F3) of the five familysuccession SMEs the new owners can be classified as Potential Successors (as defined by Rastologi and Agrawal, 2010). The successor of F3 can rather be characterised as a Potential Entrepreneur since he expresses a strong growth focus. The successors of F2 also show such signs of Potential Entrepreneur, but not as clearly, due to several owners where only one of them, the Managing Director, expressed clear growth with a strong production process innovation focus. This is in line with Melin et al. (2007) who state that succession within the family often focuses on in what ways the successor suits the intentions and will of the previous owner. When it comes to external owners, the classification is not aided by as clear a labelling but evident is that new (external) owners have a somewhat stronger focus on growth and renewal, yet none of the studied companies present any really drastic changes. Here it would have been expected that those companies taken over by industry conglomerates (N1 and N4) would have experienced the most intensive changes, but also these two companies to large extent continued as previously. Since in case N3 the previous owner still manages the business after the succession, his aims and goals will continue to influence the development of the company. Those companies that are marked by more radical innovations within new frames, are so only partially and as spin-offs from existing businesses, while the previous business also continues (F1 and F4),

The within-family succession literature describes how the take-over is either successive, or how the next generations take over only once the previous decides to retire (Ip and Jacobs, 2006). The former of these allows for better transition of knowledge (Handler, 1990), while the latter would anticipate a better ground for changing the strategic direction and hence the degree of innovation for the firm. The present study 
provides only some insights into how ideas are passed through generations and mindsets of entrepreneurial individuals (Habbershon et al., 2010), something observed in case F5 and also in N3, in turn showing that such reasoning may be as valid for external succession as family ones, while the still ongoing succession in case F4 rather demonstrates the need for the younger generation to have a clear cut vis-à-vis the older generation in managing the company. Any changes are only likely to take place some time after the effect of the legacy has withered. Yet the study shows that there seems to be a long transfer period in terms of possible re-orientation of the company's innovation focus. In the studied cases, the successor is chosen with care, indicating that the previous owner wants to ensure transfer of his/her legacy as regards what the business is all about.

In our study there are strong indications that succession within the family is less risk oriented. However, risk aversion may not be negative in any way as these companies develop at a steady, yet slow pace. On the other hand, some of the new owners with sufficient capital have been quite risk oriented with less prosperous outcome. In one case this led to an acquisition (Company N4) and in another to bankruptcy (Company N2). To dive into what was the real cause behind the bankruptcy of N2 was only partly studied, but secondary data from the new owner (2009) indicates that the previous successor could have lacked knowledge of the conditions for running this type of company with profit, contextual factors highlighted by Hussinger (2010). These cases also highlight the need to align owner and successor as pointed out by Handler (1990). This can also be illuminated by N5. The aim of its new owners, experienced in general business development from similar industrial companies, was to develop the acquired company with growth and profit in order to sell it with good profit in a few years from the succession. Instead, they had economically tough years and are still, after six years, struggling with profitability and to avoid bankruptcy.

Another aspect found among the studied SMEs is that customer dependency continues to decrease. In other words, the SMEs have increased their diversification as regards customers resulting in a decrease in risk. This means that the possible customer market intelligence should increase and how the SME will use this depends on the entrepreneurial orientation of the owner as discussed by Verhees and Meulenberg (2004), the ability de-learn (Garud, Nayyar \& Shapira, 1997) and if, there has been a familyoriented succession, on the personality of the successor (Rastologi and Agrawal, 2010).

Further, three of the new external owners in our study are of a type not frequently mentioned in succession literature (cf. Scholes et al., 2007), namely industry conglomerates consisting of SMEs within a related industry (N1, N4, and recently N2). This type of new owners does not seem to differ much from within family successors or other types of new owners, except that the industry conglomerate can exchange management persons between its firms. Still, they seem to let the company run its own business, but with stricter reporting requirements and structured governance (board of directors, board meetings), than with the previous family-owner.

\section{Conclusions}

The beginning of this paper raised two questions. These are answered below. 


\section{Depending on to whom a family-owned SME is succeeded, how can the innovativeness following the succession be characterized?}

Regardless of if the SME is succeeded to a family member or an external owner, its innovativeness to large extents continues as previously. Thus, it is mainly a within-frame (Verhees and Meulenberg, 2004), incremental innovativeness (Eng et al., 2010) led by a company owner characterized as a Potential Successors, rather than as a Potential Entrepreneur (Rastologi and Agrawal, 2010). This is marked by how the context of the company influences its future and how the present owner seems to choose successor based on a continuity of the firm.

\section{How can the aspects explaining the innovativeness following succession in a family-owned SME be described?}

Even though the present study indicates that it is just as common to remain an incremental innovator with an exploit or bounded exploration search frame if the succession is within the family as when the succession involves a new external owner, the findings from this research indicate that the view and management of innovativeness can neither simply be related to the type of new owner, nor can these aspects be fully understood from the process by which the ownership transferred. Rather, there are a number of contextual aspects that needs to be considered and understood. These include interest, knowledge, experience, loyalty, conflict management skills, risk taking and motives or drives, which controls the view on and management of innovativeness.

In sum, from the analysis we conclude that any statement like "ownership change type A will lead to view B on innovativeness” is quite futile. During our study it became evident that several of the companies refused to sell to new owners as they feared that, through the following integration, "their" company would be closed and moved elsewhere. These companies display the rootedness discussed in entrepreneurship literature (Melin et al., 2007). Such rootedness is of course from a societal economic perspective advantageous but may hinder innovations, as accesses to financial means may be (more) limited, even though the company has a desire for or interest in higher innovativeness. This attitude thus influenced the choice of succession, also pointing to that the type of succession is an independent variable affected by other circumstances.

\section{Contribution}

This paper contributes to research on succession of family-owned firms and takeovers of SMEs through researching how the innovativeness of such firms are viewed and handled in the succession. Previous research on family-owned businesses has mainly concentrated on how family issues are dealt with (e.g. Melin et al., 2007; Habbershon et al., 2010), while this paper thus points to one of the important engines for keeping a company progressing: its ability to innovative. Furthermore, the study compares this to various forms of external company takeovers of the family-owned firms, where previously literature in the area tends to focus on large firms and less is known about small firms remaining small. This paper shows that while a succession to an external party would allow for more changes to the SME, these do not come about as a consequence of contextual factors influencing the condition of the SME, and as a consequence of that the 
previous owner seems to choose a successor that wants to continue to run the firm as previously. As a consequence, innovativeness often becomes handled as by previous owners, with a focus on incremental, within frame innovations.

\section{Practical implications and further research}

This paper introduces research on innovativeness in succession of family-owned SMEs. With the very many firms being SMEs and family owned, and each of these at one point or the other, will need to succeed its ownership, this opens up a field of research for further exploitation. The cases in this paper are limited to ten and further case studies are prompted, where larger samples on various types of new owner, including the new type industry conglomerates, are included. It would also be of interest to run further in-depth analyses to explore how succeeded family-owned SMEs treat innovativeness and company renewal in the long-term perspective.

This paper shows the potential difficulties of re-orienting a family-owned SME following its succession and also that innovativeness is given limited attention in the choice of successor. For successor, it would be important to consider how the previous owner continues to influence the direction of the firm and also what contextual obstacles may influence its further development. For those handing over family-businesses to new generations or external owners, innovativeness of the firm as such would need to be given more attention in their choice of successor. The importance would not simply be to keep things as previously, but to ensure that the business remains healthy in the longterm. This awareness is important not only to the families owning the businesses but also to advisors and small-scale investors interested in acquiring a family-owned SME.

\section{References}

Ahuja G. and R. Katila (2001). "Technological acquisitions and the innovation performance of acquiring firms: A longitudinal study". Strategic Management Journal, 22(3), pp. 197-219.

At C. and P-H. Morand (2003). "The sale of small firms: a multidimensional analysis”. Economic Theory, 22, pp. 927-933.

Birley S, D. Ng and A. Godfrey (1999). "The family and the business”. Long Range Planning, 32(6), pp. 598-608.

Boeker W. and R. Karichalil (2002). "Entrepreneurial transition: Factors affecting founder departure”. Academy of Management Journal, 45(3), pp. 818-826.

Christensen K. S. (2006). "Losing innovativeness: the challenge of being acquired". Management Decision, 49(9), pp. 1161-1182.

Clark, K. B. (1985). "The interaction of design hierarchies and market concepts in technological evolution”. Research Policy, 14, pp. 235-251.

Commission Recommendation (2003). "Commission Recommendation of 6 May 2003 concerning the definition of micro, small and medium-sized enterprises". Recommendation No. 2003/361/EC, Official Journal of the European Union, No. 124, pp. 36-41.

Davidson K. M. (1988). The acquisition risk. Journal of Business Strategy, 9(3), 5658. 
de Man A-P and G. Duysters (2005). "Collaboration and innovation: a review of the effects of mergers, acquisitions and alliances on innovation”. Technovation, 25(3), 13771387.

Dosi. G. (1982) “Technological paradigms and technological trajectories. A suggested interpretation of the determinants and directions of technical change”. Research Policy, 11, pp. 147-162.

Eisenhardt, K. M. och M. E. Graebner, (2007) “Theory building from cases: Opportunities and Challenges”, Academy of Management Journal, Vol. 50, No. 1, pp. 2532.

Eng, J. N. M., A. Ledwith, and J. Bessant (2010) "Search Strategies for Discontinuous and Radical Innovation in Established Companies”. Paper presented at the 17th EIASM International Product Development Management Conference, June 13-15, Murcia, Spain. Paper available from EIASM (The European Institute for Advanced Studies in Management), Place de Brouckère-Plein 31, B - 1000 BRUSSELS, Belgium.

European Commission (2009) "Overview of Family-Business-Relevant Issues: Research, Networks, Policy Measures and Existing Studies”, Final Report of the Expert Group. [online] Available at: http://ec.europa.eu/enterprise/policies/sme/promotingentrepreneurship/family-business/ [Accessed: 2010-11-02].

Fiegener, Mark K. (2010). "Locus of Ownership and Family Involvement in Small Private Firms”, Journal of Management Studies, March, Vol. 47 Issue 2, pp. 296-321.

Fillion E. P. J. (1966). “A way out for small business”. Advanced Management Journal, pp. 27-33.

Garud, R., Nayyar, P. R. and Shapira, Z. B (1997). "Beating the odds: Toward a theory of technological innovation”. In: Garud, R., Nayyar, P. R. and Shapira, Z. B. (eds.) Technological innovation: oversights and foresights. Cambridge: Cambridge University Press.

Habbershon, T. G., M. Nordqvist and T. M. Zellweger (2010) "Transgenerational entrepreneurship”. In Transgenerational Entrepreneurship: Exploring Growth and Performance of Family Firms across Generations, Nordqvist M. \& T. Zellweger (eds) [online] Available at: http://www.alexandria.unisg.ch/publications/54561/L-en, [Accessed: 2010-10-15].

Handler WC (1990). "Succession in family firms: A mutual role adjustment between entrepreneur and next-generation family members". Entrepreneurship Theory and Practice, pp. 37-51.

Hurley, R. F., and G.T. M. Hult (1998). "Innovation, Market Orientation, and Organizational Learning: An Integration and Emperical Examination”, Journal of Marketing, 62(3), pp. 42-54.

Hussinger K (2010). "On the importance of technological relatedness: SMEs versus large acquisition targets”, Technovation, 30, pp. 57-64.

Ip, B., and G. Jacobs (2006) "Business succession planning: a review of the evidence”, Journal of Small Business and Enterprise Development, Vol. 13, No. 3, pp. 326-350.

LaForet, S and J. Tann (2006) "Innovative characteristics of small manufacturing firms”, Journal of Small Business and Enterprise Development, Vol. 13 No. 3, pp. 363380.

Levinthal, D. (1997). “Three faces of organizational learning: Wisdom, inertia, and discovery”. In: Garud, R., Nayyar, P. R. and Shapira, Z. B. (eds.) Technological innovation: oversights and foresights. Cambridge: Cambridge University Press. 
Ljung, M. (2010) Småföretagslandet Sverige [html] (Updated 2010-09-06) Available at: http://www.ekonomifakta.se/sv/Artiklar/2010/September/Smaforetagslandet-Sverige/. [Accessed September 20, 2010].

Madrid-Guijarro, A., Garcia, D. and Van Auken, H. (2009) "Barriers to Innovation among Spanish Manufacturing SMEs”, Journal of Small Business Management, Vol. 47, Issue 4, October, pp. 465-488.

Melin, L., Brundin, E., Haag, K., Hall, A., Nordqvist, M., and Wigren, C. (2007). Ägarskifte med förnuft och känsla: Vägledning inför ägar- och ledarskiften i företag. Stockholm: Verket för näringslivsutveckling

Mosey, S., Clare, J. N. and Woodcock, D. J (2002) "Innovation decision making in British manufacturing SMEs”, Integrated Manufacturing Systems, 13/3, p. 176-183.

Öberg, C., C. Grundström, and P. Jönsson, P. (2011). ”Acquisitions and network identity change”. European Journal Marketing. In press.

Pratt, M. G. (2009) "For the lack of a boilerplate: Tips on writing up (and rewriting) qualitative research”, Academy of Management Journal, Vol. 52, No. 5, pp. 856-862.

Ragozzino R. and J.J. Reuer (2007). "Initial public offerings and acquisition of entrepreneurial firms”. Strategic Organization, 5(2), pp. 155-176.

Rastogi, S. and R. Agrawal (2010). "Intention of the offspring to join family enterprise: a study of Indian businesses”, Annals of Innovation \& Entrepreneurship, 1: 5603 - DOI: 10.3402/aie.v1i1.5603, Available at: http://www.innovationandentrepreneurship.net, [Accessed 2010-10-14].

Sahal, D. (1981). Patterns of Technological Innovation. Reading, MA: AddisonWesley Publishing Company, Inc.

Salvato C, U Lassini and J Wiklund (2007). "Dynamics of external growth in SMEs: A process model of acquisition capabilities emergence”. Schmalenbach Business Review, 59, pp. 282-305.

Scholes M.L., M. Wright, P. Westhead, A. Burrows and H. Bruining (2007). "Information Sharing, price negotiation and management buy-outs of private-owned firms”. Small Business Economics, 29, pp. 329-349.

Trevinyo-Rodríguez, R. N. and N. Bontis (2010). "Family ties and emotions: a missing piece in the knowledge transfer puzzle”, Journal of Small Business and Enterprise Development, Vol. 17 No. 3, pp. 418-436.

Tushman, M. L., and Murmann, J. P. (1998). "Dominant Designs, Technology Cycles, and Organizational Outcomes”. Research in Organizational Behavior, Volume 20, pp. 231-266.

Verhees, F. J. H. M., and M. T. G. Meulenberg, (2004). "Market Orientation, Innovativeness, Product Innovation, and Performance in Small Firms”, Journal of Small Business Management, Vol. 42, Issue 2, April, pp. 134-154

Zajac E (1990). "CEO selection, succession, compensation and firm performance: a theoretical integration and empirical analysis”. Strategic Management Journal, 11, pp217-230 